\title{
Aplikasi Transformasi Fourier untuk Menentukan Periode Curah Hujan (Studi Kasus: Periode Curah Hujan di Kabupaten Seram Bagian Barat, Provinsi Maluku)
}

\author{
Vendira H. P. Noya, F.Y. Rumlawang, Y. A. Lesnussa \\ Jurusan Matematika, Fakultas Matematika dan Ilmu Pengetahuan Alam, \\ Universitas Pattimura Ambon \\ Jl. Ir. M. Putuhena, Kampus Unpatti Poka-Ambon \\ vendiranoya@yahoo.co.id,rumlawang@yahoo.com,yopi_a_lesnussa@yahoo.com
}

\begin{abstract}
ABSTRAK
Kabupaten Seram Bagian Barat merupakan salah satu daerah di Maluku yang memiliki curah hujan yang cukup tinggi selain intensitas terjadinya hujan yang tinggi. Adanya kecenderungan perubahan cuaca yang tidak menentu saat ini, mengakibatkan pentingnya mengetahui informasi tentang banyaknya curah hujan dengan cara mengetahui periode dari curah hujan tersebut. Dengan demikian diharapkan dapat memberikan konstribusi untuk prakiraan curah hujan nantinya, sehingga memperlancar proses aktifitas kehidupan masyarakat. Data curah hujan Kabupaten Seram Bagian Barat dianalisis dengan menggunakan Fast Fourier Transform (FFT) dimana data tersebut diinputkan dan dianalisis menggunakan bantuan program Matlab. Data curah hujan diperoleh dari Badan Meteorologi Klimatologi dan Geofisika Ambon yang berupa data curah hujan bulanan dari tahun 1991 sampai dengan tahun 2009. Hasil penelitian menunjukan bahwa periode curah hujan pada Kabupaten Seram Bagian Barat adalah 12 bulan.
\end{abstract}

Kata Kunci: Curah Hujan, FFT, Fourier, Periode

\section{ABSTRACT}

\begin{abstract}
Seram Bagian Barat is one of some areas in Moluccas that has high rainfall intensity beside the intensity occur of rain. Lately, there is an inclination of weather change uncertainly so that it is important to have more information about how many rainfall by knowing the period of the rainfall. Thus, this research is expected can give contribution for estimate rainfall later, so that it makes the process of society life activity be easier. Rainfall data of Seram Bagian Barat Regency is analysed using FFT (Fast Fourier Transform) where the data will be inputted and analysed using Matlab program. The rainfall data got from BMKG Ambon that as monthly rainfall data since 1991 until 2009. The result of this research shows that the period of rainfall at Seram Bagian Barat Regency is 12 month.
\end{abstract}

Keywords:Rainfall, FFT, Fourier, Period

\section{Pendahuluan}

Cuaca merupakan kondisi fisis atmosfer dalam kurun waktu yang singkat. Kondisi ini selalu berubah - ubah secara tidak beraturan dalam kurun waktu tertentu, sehingga sulit bagi seseorang untuk memprediksi cuaca secara tepat. Informasi cuaca merupakan kebutuhan utama untuk mendukung kegiatan di berbagai sektor. Informasi tersebut dapat berupa prakiraan curah hujan.Curah hujan adalah jumlah air yang jatuh di permukaan tanah datar, tidak menguap dan tidak mengalir selama periode tertentu yang diukur dengan satuan $(\mathrm{mm})$ pada luasan $1 \mathrm{~m}^{2}$. Informasi tentang banyaknya curah hujan adalah salah satu unsur penting dan besar pengaruhnya terhadap segala macam aktifitas kehidupan seperti: keselamatan masyarakat, produksi pertanian, perkebunan, perikanan, penerbangan, pelayanan publik, dan sebagainya.

Kabupaten Seram Bagian Barat merupakan salah satu daerah di Maluku yang dikenal sebagai lumbung pangan penghasil sayur - sayuran dan beras. Sebagian besar penduduk 
setempat memperoleh penghasilan dari bidang pangan ini. Dengan demikian, pengetahuan akan periode curah hujan akan sangat berguna dalam menentukan waktu tanam yang tepat.Untuk menentukan besar periode curah hujan di suatu daerah, dapat digunakan berbagai metode pemrosesan sinyal. Sampai sekarang Transformasi Fourier masih menjadi transformasi yang paling popular untuk menentukan periode curah hujan.

AnalisisFourier adalah sebuah perangkat matematika untuk mentransformasi data dari informasi waktu ke informasi frekuensi. Dari hasil frekuensi inilah maka akan diperoleh suatu periode maksimum dari curah hujan suatu daerah. Oleh karena itu, dilakukan penelitian dengan judul "Aplikasi Transformasi Fourier untuk Menentukan Periode Curah Hujan (Studi Kasus: Periode Curah Hujandi Kabupaten Seram Bagian Barat, Provinsi Maluku)".

\section{Kajian Pustaka}

\subsection{Transformasi Fourier}

Selain adanya Deret Fourier, juga dikenal adanya Transformasi Fourier (Fourier Transform). Joseph Fourier mengemukakan bahwa sebuah fungsi periodik dapat direpresentasikan dengan mengkombinasikan penjumlahan tak hingga dari fungsi sinus dan cosinus. Representasi fungsi inilah yang kemudian dikenal sebagai Deret Fourier. Beberapa tahun setelah penemuan ini, Deret Fourier dikembangkan menjadi bentuk yang lebih umum sehingga dapat diterapkan pada fungsi yang non-periodik, bentuk yang lebih umum ini yang kemudian dikenal sebagai Transformasi Fourier (lihat Kreyszig, [3]).

Biasanya sebuah fungsi digambarkan dalam domain waktu, artinya yang diukur dari fungsi tersebut adalah waktu. Dengan kata lain, jika fungsi tersebut digambarkan pada sumbu simetri, maka sumbux (sebagai variabel bebas) mewakili waktu, dan sumbu y (sebagai variabel tak bebas) mewakili nilai pada waktu $t$ tertentu, atau nilai amplitudonya (lihat La Budiani [4]). Pada aplikasinya, representasi ini tidak selalu merupakan representasi terbaik. Pada banyak kasus, informasi khusus tersembunyi pada nilai frekuensinya.

Dengan menggunakan Analisis Fourier maka representasi waktu-amplitudo akan ditransformasikan sehingga menjadi representasi frekuensi-amplitudo. Artinya sumbu $x$ mewakili frekuensi dan sumbu $y$ mewakili nilai amplitudonya. Seperti yang diperlihatkan pada Gambar 1.
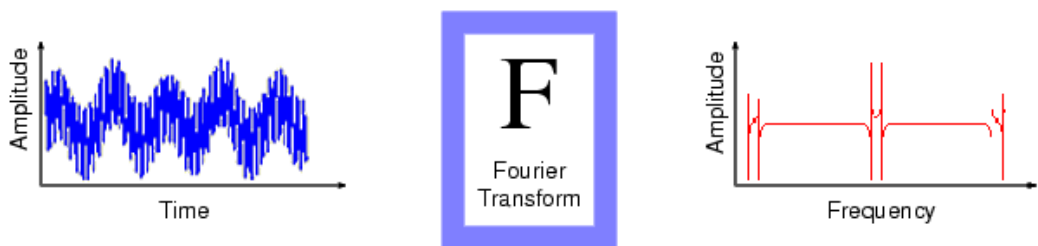

Gambar 1. Analisis Fourier

Transformasi Fourier bersifat reversibel, yaitu suatu fungsi dapat ditransformasi ke dalam domain frekuensi (yang memuat informasi frekuensi-amplitudo), dan di inversikan lagi ke domain waktu (yang memuat informasi waktu-amplitudo). Namun, kedua informasi tersebut tidak bisa didapatkan secara bersamaan. Representasi fungsi dalam domain frekuensi tidak memuat informasi waktu, demikian pula sebaliknya. 
Transformasi Fourier diperoleh dari integral Fourier dalam bentuk kompleks (lihat Febriani [2]). Bentuk dari Transformasi Fourier adalah

$$
\hat{f}(\mathrm{w})=\frac{1}{2 \pi} \int_{-\infty}^{\infty} f(x) e^{i w x} d .
$$

\subsection{Transformasi Fourier Diskrit}

Transformasi Fourier Diskrit atau disebut dengan Discrete Fourier Transform (DFT) adalah model transformasi Fourier yang dikenakan pada fungsi diskrit, dan hasilnya juga diskrit (lihat Budiyanto [1]).

Misalkan $f(x)$ periodik. Diasumsikan $N$ merupakan bagian - bagian yang diukur dari $f(x)$ yang diambil pada interval $0 \leq x \leq 2 \pi$ dengan jarak yang teratur dari titik-titik

$$
x_{k}=\frac{2 \pi k}{N}, k=0,1 \ldots, N-1 \text {. }
$$

DFT didefinisikan dengan:

$$
\hat{f}_{j}=\sum_{k=0}^{N-1} f_{k} e^{i j x_{k}}, f_{k}=f\left(x_{k}\right), j=0, \ldots, N-1
$$

Persamaan (1) inilah yang akan menghasilkan spektrum frekuensi dari sinyal. Misal diberikan

$$
e_{j k}=e^{-i j x_{k}}=e^{-\frac{2 \pi i j k}{N}}=w^{j k}, w=w_{N}=e^{-\frac{2 \pi i}{N}}
$$

dimana $j, k=0, \ldots, N-1$. DFT seperti pada Persamaan (1) dinamakan dengan DFT 1 dimensi, DFT semacam ini banyak digunakan dalam pengolahan sinyal digital.

\subsection{Transformasi Fourier Cepat}

Aplikasi langsung dari definisi DFT untuk data vektor dengan panjang $N$ membutuhkan $N$ perkalian dan $N$ penjumlahan. Sehingga jika digunakan $N$ dalam jumlah yang besar akan menimbulkan jutaan operasi perhitungan DFT. Untuk memudahkan perhitungan, muncullah teknik Transformasi Fourier Cepat atau Fast Fourier Transform (FFT) (Kreyszig, [3]).

FFT merupakan DFT yang memiliki jumlah komputasi lebih sedikit dibanding komputasi DFT biasa. DFT akan menghasilkan jumlah komputasi sebesar $N^{2}$ sedangkan $F F T$ akan menghasilkan jumlah komputasi sebesar $(N) \log _{2}(N)$. Sehingga $F F T$ menjadi metode praktis DFT untuk $N$ dalam jumlah yang besar. Dengan mensubstitusikan Persamaan (2) pada Persamaan (1) maka persamaan untuk DFT berubah menjadi

$$
\hat{f}_{j}=\sum_{k=0}^{N-1} w_{N}^{k_{j}} f_{k} \text {. }
$$

Misalkan bahwa $N$ dapat dibagi menjadi 2 sehingga Persamaan (3) dibagi menjadi 2 bagian yaitu untuk $k$ genap dan $k$ ganjil. Selanjutnya, diberikan variabel baru dengan

$$
M=\frac{N}{2}
$$


Sehingga diperoleh

$$
\hat{f}_{j}=\sum_{k=0}^{M-1} w_{N}^{2 k j} f_{2 k}+\sum_{k=0}^{M-1} w_{N}^{(2 k+1) j} f_{2 k+1}
$$

Jika diketahui bahwa

$$
w_{N}^{2}=\left(e^{-\frac{2 \pi i}{N}}\right)^{2}=e^{-\frac{4 \pi i}{2 M}}=e^{-\frac{2 \pi i}{M}}=w_{M}
$$

maka dengan mensubstitusi Persamaan (5) pada Persamaan (4) maka diperoleh

$$
\hat{f}_{j}=\sum_{k=0}^{M-1} w_{M}^{k j} f_{2 k}+w_{N}^{j} \sum_{k=0}^{M-1} w_{M}^{k j} f_{2 k+1} .
$$

Setelah domain waktu dibagi 2 maka domain frekuensi juga dibagi 2 sehingga dengan membagi frekuensi pada Persamaan (6) maka

$$
(x+a)^{n}=\sum_{k=0}^{n}\left(\begin{array}{l}
n \\
k
\end{array}\right) x^{k} a^{n-k}=\sum_{k=0}^{M-1} w_{M}^{k j} w_{M}^{M} f_{2 k}+w_{N}^{j} w_{N}^{M} \sum_{k=0}^{M-1} w_{M}^{k j} w_{M}^{M} f_{2 k+1}
$$

Karena $w_{M}^{M}=1$ dan $w_{N}^{M}=1$, Persamaan (7) menjadi

$$
\hat{f}_{j+M}=\sum_{k=0}^{M-1} w_{M}^{k j} f_{2 k}-w_{N}^{j} \sum_{k=0}^{M-1} w_{M}^{k j} f_{2 k+1}
$$

dimana $N$ adalah banyaknya data,

$$
M=\frac{N}{2} M=\frac{N}{2} ; w_{N}=e^{\frac{-2 \pi i}{N}} ; w_{M}=e^{\frac{-2 \pi i}{M}} ; k, j=0,1, \ldots, N-1 .
$$

Persamaan inilah yang dikenal dengan $F F T$.

\section{Hasil dan Pembahasan}

Pada bagian pembahasan dilakukan analisis fourier berdasarkan data curah hujan Kabupaten Seram Bagian Barat yang diperoleh dari Badan Meteorologi Klimatologi dan Geofisika Ambon selama 19 tahun sejak tahun 1991 sampai dengan tahun 2009.

Penentuan periode curah hujan pada penelitian ini dilakukan dengan menggunakan Transformasi Fourier. Gambar 2 merupakan bentuk sinyal dari data curah hujan pada Kabupaten Seram Bagian Barat. Sumbu $x$ menyatakan bulan selama 19 tahun sedangkan sumbu $y$ menyatakan data curah hujan yang dinyatakan dalam milimeter $(\mathrm{mm})$. Seperti yang terlihat pada Gambar 2, diperoleh data curah hujan bulanan yang tertinggi mencapai $944 \mathrm{~mm}$ yaitu pada bulan Juni 2007 atau pada bulan ke-198, dan terendah adalah $5 \mathrm{~mm}$ yaitu pada bulan Oktober 2007 atau pada bulan ke-202.

Untuk memperoleh periode siklus curah hujan Kabupaten Seram Bagian Barat, mula mula digunakan FFT dan setelah diperoleh frekuensi, digunakan kebalikan dari frekuensi. Untuk memperoleh frekuensi digunakan fungsi pada MATLAB, yaitu fungsi FFT.

Perhitungan FFT untuk 10 data pada penelitian ini yaitu untuk bulan Januari sampai dengan Mei untuk tahun 1991 dan 1992, dengan data seperti berikut:

$$
A=\left[\begin{array}{llllllllll}
163 & 141 & 63 & 107 & 170 & 47 & 47 & 117 & 143 & 120
\end{array}\right]
$$




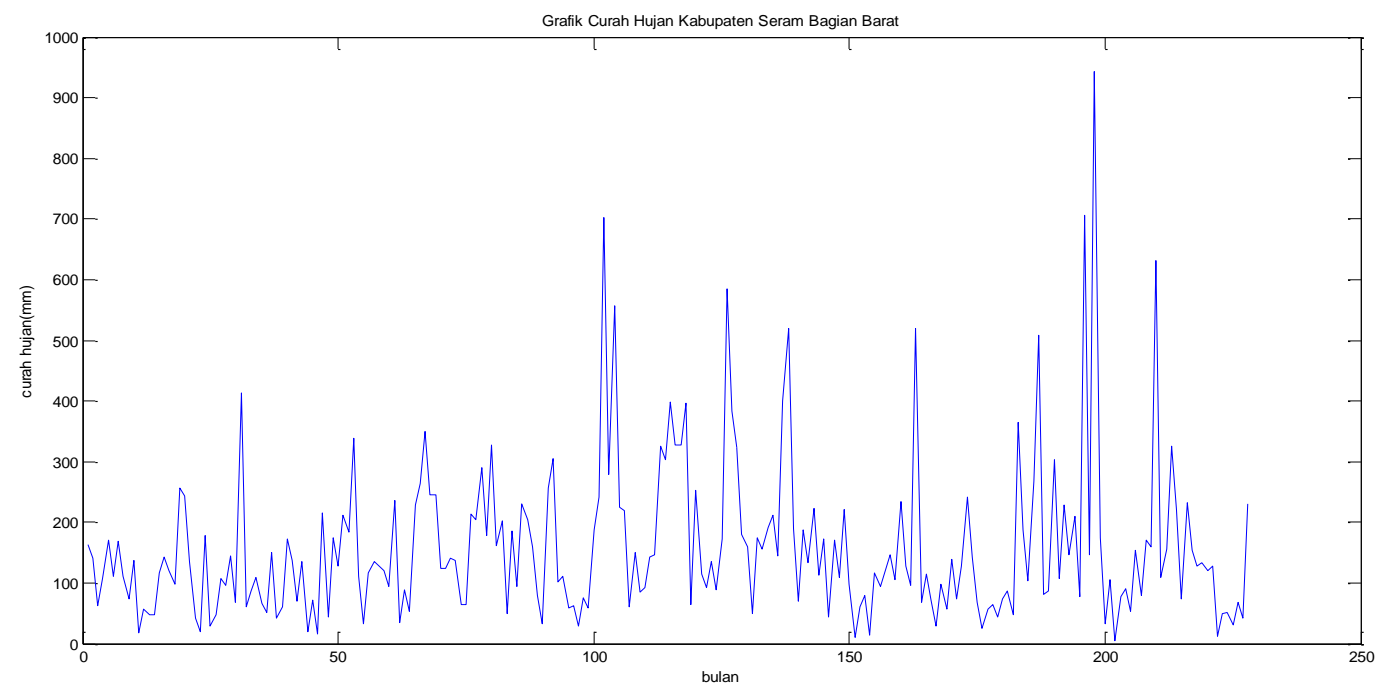

Gambar 2. Data Curah Hujan Kabupaten Seram Bagian Barat

Dengan menggunakan perintah $y=F F T(A)$ pada program Matlab, diperoleh $y=1 \times 10^{3}$ dengan $y=\hat{f}_{j}$ merupakan hasil transformasi dari $A$, yaitu

$$
\begin{aligned}
& \hat{f}_{0}=1.1180 \\
& \hat{f}_{1}=0.1460+0.0010 \mathrm{i} \\
& \hat{f}_{2}=0.0098+0.1382 \mathrm{i} \\
& \hat{f}_{3}=0.1170-0.1899 \mathrm{i} \\
& \hat{f}_{4}=-0.0438-0.0066 i \\
& \hat{f}_{5}=0.0540 \\
& \hat{f}_{6}=-0.0438+0.0066 \mathrm{i} \\
& \hat{f}_{7}=0.1170+0.1899 \mathrm{i} \\
& \hat{f}_{8}=0.0098-0.1382 \mathrm{i} \\
& \hat{f}_{9}=0.1460-0.0010 i
\end{aligned}
$$

Secara matematika dapat dilakukan perhitungan FFT dengan menggunakan Persamaan (7) dan Persamaan (8) seperti berikut :

$$
\begin{aligned}
& N=10 \\
& M=\frac{N}{2}=\frac{10}{2}=5 \\
& w_{N}=w_{10}=e^{-\frac{2 \pi i}{10}}=e^{-\frac{\pi i}{5}}=\cos \left(\frac{\pi}{5}\right)-i \sin \left(\frac{\pi}{5}\right)=\cos (36)-i \sin (36)=0.8090-0.5878 \mathrm{i}, \\
& w_{M}=w_{5}=e^{-\frac{2 \pi i}{5}}=\cos \left(\frac{2 \pi}{5}\right)-i \sin \left(\frac{2 \pi}{5}\right)=\cos (72)-i \sin (72)=0.3090-0.9511 \mathrm{i}
\end{aligned}
$$

dengan $k, j=0,1, \ldots, 9$. 
Selanjutnya misalkan Persamaan (6) dan Persamaan (8) disederhanakan dengan variabel baru $E_{j}$ untuk fungsi genap dan $O_{j}$ untuk fungsi ganjil

$$
\sum_{k=0}^{M-1} w_{M}^{k j} f_{2 k}=E_{j}
$$

dan

$$
\sum_{k=0}^{M-1} w_{M}^{k j} f_{2 k+1}=O_{j}
$$

maka Persamaan (6) menjadi

$$
\hat{f}_{j}=E_{j}+w_{N}^{j} O_{j}
$$

dan Persamaan (8) menjadi

$$
\hat{f}_{j+M}=E_{j}-w_{N}^{j} O_{j}
$$

Diperoleh untuk fungsi genap

$$
\begin{aligned}
E_{j} & =\sum_{k=0}^{M-1} w_{M}^{k j} f_{2 k}=\left[\begin{array}{lllll}
w_{5}^{0} & w_{5}^{0} & w_{5}^{0} & w_{5}^{0} & w_{5}^{0} \\
w_{5}^{0} & w_{5}^{1} & w_{5}^{2} & w_{5}^{2} & w_{5}^{4} \\
w_{5}^{0} & w_{5}^{2} & w_{5}^{4} & w_{5}^{6} & w_{5}^{8} \\
w_{5}^{0} & w_{5}^{2} & w_{5}^{6} & w_{5}^{9} & w_{5}^{12} \\
w_{5}^{0} & w_{5}^{4} & w_{5}^{9} & w_{5}^{12} & w_{5}^{16}
\end{array}\right]\left[\begin{array}{l}
f_{0} \\
f_{2} \\
f_{4} \\
f_{6} \\
f_{8}
\end{array}\right] \\
& =\left[\begin{array}{lllll}
(0.3090-0.9511 i)^{0} & (0.3090-0.9511 i)^{0} & (0.3090-0.9511 i)^{0} & (0.3090-0.9511 i)^{0} & (0.3090-0.9511 i)^{0} \\
(0.3090-0.9511 i)^{0} & (0.3090-0.9511 i)^{1} & (0.3090-0.9511 i)^{2} & (0.3090-0.9511 i)^{2} & (0.3090-0.9511 i)^{4} \\
(0.3090-0.9511 i)^{0} & (0.3090-0.9511 i)^{2} & (0.3090-0.9511 i)^{4} & (0.3090-0.9511 i)^{6} & (0.3090-0.9511 i)^{8} \\
(0.3090-0.9511 i)^{0} & (0.3090-0.9511 i)^{2} & (0.3090-0.9511 i)^{6} & (0.3090-0.9511 i)^{9} & (0.3090-0.9511 i)^{12} \\
(0.3090-0.9511 i)^{0} & (0.3090-0.9511 i)^{4} & (0.3090-0.9511 i)^{9} & (0.3090-0.9511 i)^{12} & (0.3090-0.9511 i)^{16}
\end{array}\right]\left[\begin{array}{c}
163 \\
63 \\
170 \\
47 \\
143
\end{array}\right]
\end{aligned}
$$

$$
\begin{aligned}
& =\left[\begin{array}{ccccc}
1 & 1 & 1 & 1 & 1 \\
1 & (0.3090-0.9511 i)^{1} & (0.3090-0.9511 i)^{2} & (0.3090-0.9511 i)^{2} & (0.3090-0.9511 i)^{4} \\
1 & (0.3090-0.9511 i)^{2} & (0.3090-0.9511 i)^{4} & (0.3090-0.9511 i)^{6} & (0.3090-0.9511 i)^{8} \\
1 & (0.3090-0.9511 i)^{2} & (0.3090-0.9511 i)^{6} & (0.3090-0.9511 i)^{9} & (0.3090-0.9511 i)^{12} \\
1 & (0.3090-0.9511 i)^{4} & (0.3090-0.9511 i)^{9} & (0.3090-0.9511 i)^{12} & (0.3090-0.9511 i)^{16}
\end{array}\right]\left[\begin{array}{c}
163 \\
63 \\
170 \\
47 \\
143
\end{array}\right] \\
& =\left[\begin{array}{c}
586 \\
51.10+3.79 \mathrm{i} \\
63.40+164.00 \mathrm{i} \\
63.40-164.00 \mathrm{i} \\
51.10-3.79 \mathrm{i}
\end{array}\right]
\end{aligned}
$$

Untuk fungsi ganjil

$$
O_{j}=\sum_{k=0}^{M-1} w_{M}^{k j} f_{2 k+1}=\left[\begin{array}{ccccc}
w_{5}^{0} & w_{5}^{0} & w_{5}^{0} & w_{5}^{0} & w_{5}^{0} \\
w_{5}^{0} & w_{5}^{1} & w_{5}^{2} & w_{5}^{2} & w_{5}^{4} \\
w_{5}^{0} & w_{5}^{2} & w_{5}^{4} & w_{5}^{6} & w_{5}^{8} \\
w_{5}^{0} & w_{5}^{2} & w_{5}^{6} & w_{5}^{9} & w_{5}^{12} \\
w_{5}^{0} & w_{5}^{4} & w_{5}^{9} & w_{5}^{12} & w_{5}^{16}
\end{array}\right]\left[\begin{array}{l}
f_{1} \\
f_{3} \\
f_{5} \\
f_{7} \\
f_{9}
\end{array}\right]
$$




$$
=\left[\begin{array}{ccccc}
(0.3090-0.9511 i)^{0} & (0.3090-0.9511 i)^{0} & (0.3090-0.9511 i)^{0} & (0.3090-0.9511 i)^{0} & (0.3090-0.9511 i)^{0} \\
(0.3090-0.9511 i)^{0} & (0.3090-0.9511 i)^{1} & (0.3090-0.9511 i)^{2} & (0.3090-0.9511 i)^{2} & (0.3090-0.9511)^{4} \\
(0.3090-0.9511 i)^{0} & (0.3090-0.9511 i)^{2} & (0.3090-0.9511 i)^{4} & (0.3090-0.9511 i)^{6} & (0.3090-0.9511 i)^{8} \\
(0.3090-0.9511 i)^{0} & (0.3090-0.9511 i)^{2} & (0.3090-0.9511 i)^{6} & (0.3090-0.9511 i)^{9} & (0.3090-0.9511 i)^{12} \\
(0.3090-0.9511 i)^{0} & (0.3090-0.9511 i)^{4} & (0.3090-0.9511 i)^{9} & (0.3090-0.9511 i)^{12} & (0.3090-0.9511 i)^{16}
\end{array}\right]\left[\begin{array}{c}
141 \\
107 \\
47 \\
117 \\
120
\end{array}\right]
$$

$=\left[\begin{array}{ccccc}1 & 1 & 1 & 1 & 1 \\ 1 & (0.3090-0.9511 i)^{1} & (0.3090-0.9511 i)^{2} & (0.3090-0.9511 i)^{2} & (0.3090-0.9511 i)^{4} \\ 1 & (0.3090-0.9511 i)^{2} & (0.3090-0.9511 i)^{4} & (0.3090-0.9511 i)^{6} & (0.3090-0.9511 i)^{8} \\ 1 & (0.3090-0.9511 i)^{2} & (0.3090-0.9511 i)^{6} & (0.3090-0.9511 i)^{9} & (0.3090-0.9511 i)^{12} \\ 1 & (0.3090-0.9511 i)^{4} & (0.3090-0.9511 i)^{9} & (0.3090-0.9511 i)^{12} & (0.3090-0.9511 i)^{16}\end{array}\right]\left[\begin{array}{c}141 \\ 107 \\ 47 \\ 117 \\ 120\end{array}\right]$

$$
=\left[\begin{array}{c}
532 \\
78.47+53.51 i \\
8.03-58.93 i \\
8.03+58.93 i \\
78.47-53.51 i
\end{array}\right]
$$

Selanjutnya karena perhitungannya berulang $\frac{N}{2}$ maka dengan menggunakan Persamaan (9) dan Persamaan (10) diperoleh :

$$
\begin{aligned}
\hat{f}_{0}= & E_{0}+w_{N}^{0} O_{0} \\
& =586+\left((0.8090-0.5878 \mathrm{i})^{0} \times 532\right) \\
& =586+(1 \times 532) \\
& =586+532 \\
& =1118 \\
& \\
\hat{f}_{1}= & E_{1}+w_{N}^{1} O_{1} \\
& =(51.1+3.79 i)+\left((0.8090-0.5878 \mathrm{i})^{1} \times(78.47+53.51 i)\right) \\
& =(51.1+3.79 i)+((0.8090-0.5878 \mathrm{i}) \times(78.47+53.51 i)) \\
& =(51.1+3.79 i)+(94.9354-2.8351 i) \\
& =146.0354+0.9549 i \\
\hat{f}_{2} & =E_{2}+w_{N}^{2} O_{2} \\
& =(63.40+164.00 \mathrm{i})+\left((0.8090-0.5878 \mathrm{i})^{2} \times(8.03-58.93 \mathrm{i})\right) \\
& =(63.40+164.00 \mathrm{i})+((0.3090-0.9511 i) \times(8.03-58.93 \mathrm{i})) \\
& =(63.40+164.00 \mathrm{i})+(-53.5644-25.8474 i) \\
& =9.8356+138.1526 i \\
& \\
& \\
\hat{f}_{9}= & E_{4}-w_{N}^{4} O_{4} \\
& =(51.10-3.79 \mathrm{i})-\left((0.8090-0.5878 \mathrm{i})^{4} \times(78.47-53.51 \mathrm{i})\right) \\
& =(51.10-3.79 \mathrm{i})-((-0.8090-0.5878 i) \times(78.47-53.51 \mathrm{i})) \\
& =(51.10-3.79 \mathrm{i})-(-94.9354-2.8351 i) \\
& =146.0354-0.9550 i
\end{aligned}
$$

Hasil dari Transformasi Fourier menghasilkan bagian riil dan imajiner. Selanjutnya spektrum frekuensi Fourier diperoleh dari jarak (magnitude) koefisien Fourier tersebut. Besarnya magnitude dari sumbu y disebut power. Selanjutnya power ini diplot dengan frekuensi dan hasilnya disebut periodegram seperti yang terlihat pada Gambar 3. 
Periodegram pada Gambar 3 merupakan hasil pemplotan frekuensi dan amplitudonya (power). Berbeda dengan Gambar 2, pada Gambar 2 data setiap bulan (waktu) diplot dengan besarnya curah hujan (amplitudo). Sedangkan, Gambar 3 merupakan hasil transformasi dari waktu menjadi frekuensi. Sehingga Gambar 3 memuat frekuensi dan besar amplitudo dari frekuensi tersebut.

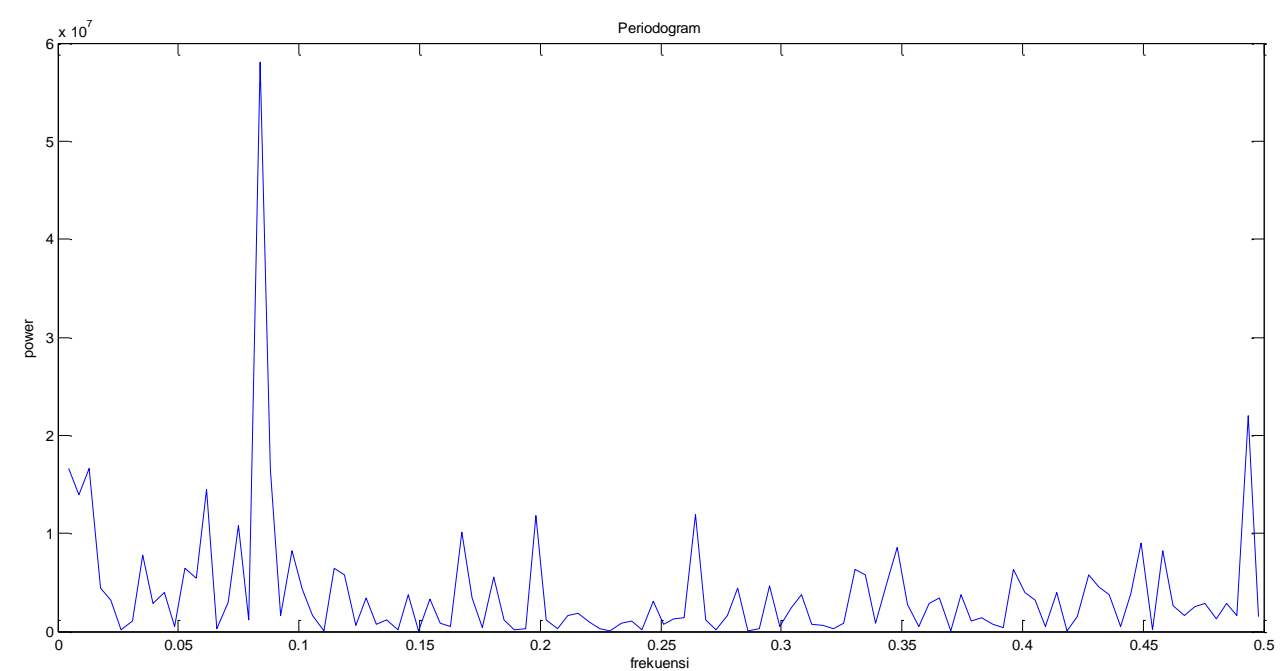

Gambar 3. Periodegram

Untuk lebih mempermudah dalam menganalisis data, maka periodegram pada Gambar 3 tersebut dipotong dengan rentang yang memuat power yang besar (mencolok) yaitu dengan memperbesar skalanya menjadi rentang frekuensi antara 0 sampai dengan 0.2 Hertz, yang dapat dilihat pada Gambar 4 .

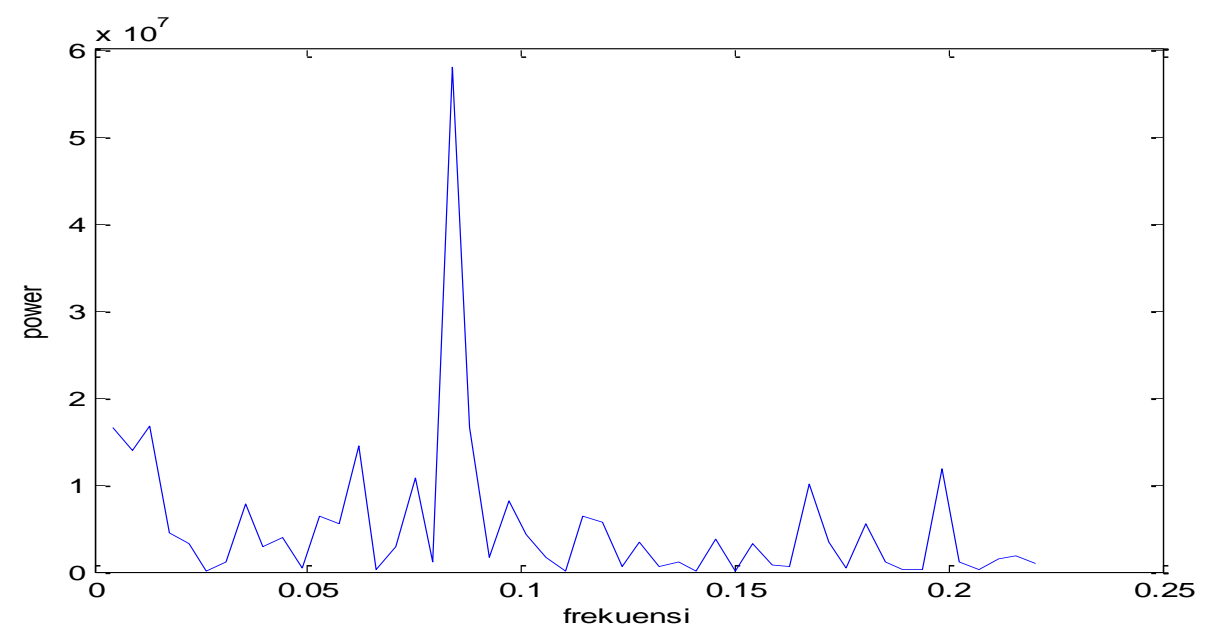

Gambar 4. Periodegram dengan skala 0 sampai dengan $0.2 \mathrm{Hertz}$

Selanjutnya dengan menggunakan kebalikan dari frekuensi yaitu

$$
T=\frac{1}{f}
$$

Diperoleh periode dari curah hujan Kabupaten Seram Bagian Barat yang diperlihatkan pada Gambar 5. 


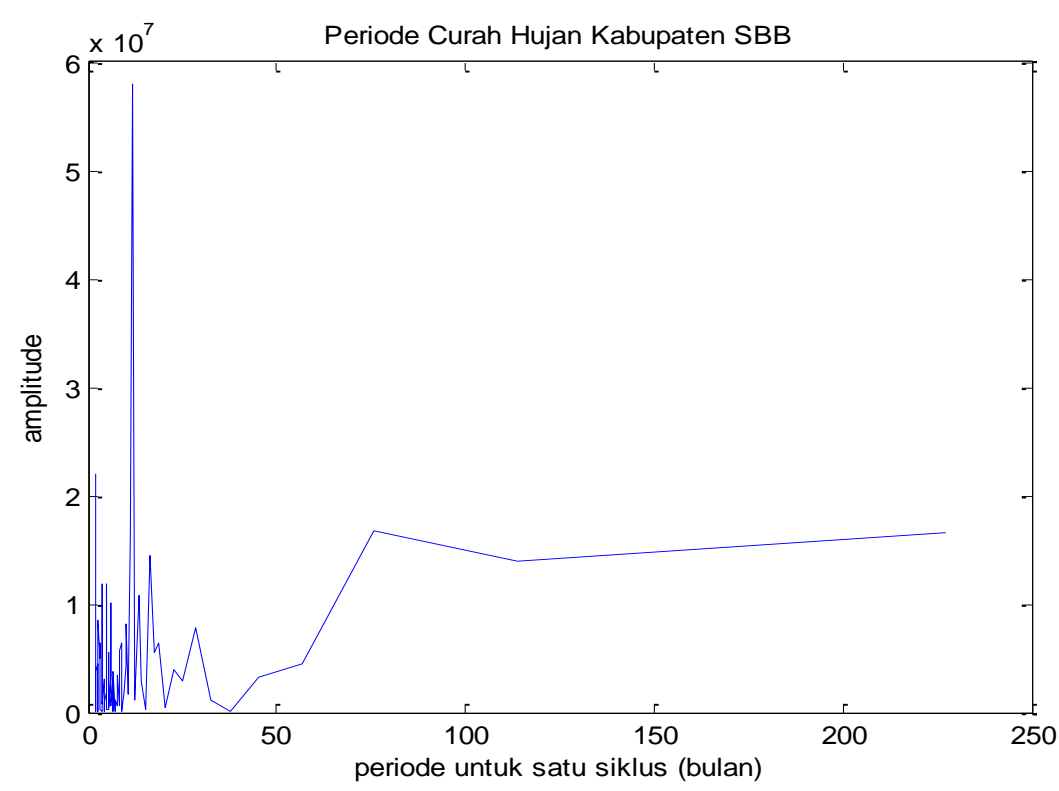

Gambar 5. Periode Curah Hujan Kabupaten Seram Bagian Barat

Gambar 5 menghasilkan periode curah hujan Kabupaten Seram Bagian Barat untuk satu siklus. Karena gambar tersebut terlalu lebar, untuk memudahkan penganalisisan data, gambar tersebut dipersempit dan disajikan dalam Gambar 6. Berdasarkan Gambar 6 diperoleh bahwa periode curah hujan maksimum pada Kabupaten Seram Bagian barat terletak pada rentang waktu 10-15 bulan yang diketahui lebih detailnya menggunakan bantuan program Matlab.

Dari data tersebut diperoleh nilai periode maksimum curah hujan dalam kurun waktu 19 tahun sejak tahun 1991 sampai dengan tahun 2009 adalah 11,9474 bulan. Sehingga disimpulkan bahwa Kabupaten Seram Bagian Barat memiliki periode curah hujan maksimum yaitu sebesar 12 bulan.

\section{Simpulan}

Berdasarkan penelitian yang dilakukan, dapat diambil kesimpulan yaitu:

1. Periode curah hujan maksimum pada Kabupaten Seram Bagian Barat adalah sebesar 12 bulan.

2. Penggunaan metode FFT pada persamaan $\hat{f}_{j}=E_{j}+w_{N}^{j} O_{j}$ dan $\hat{f}_{j+M}=E_{j}-w_{N}^{j} O_{j}$ sangat penting dalam menghitung frekuensi untuk menentukanperiodecurahhujan. Dengan menghitung FFT, diperoleh frekuensi yang menjadi dasar dalam menghitung periode curah hujan pada penelitian ini. 


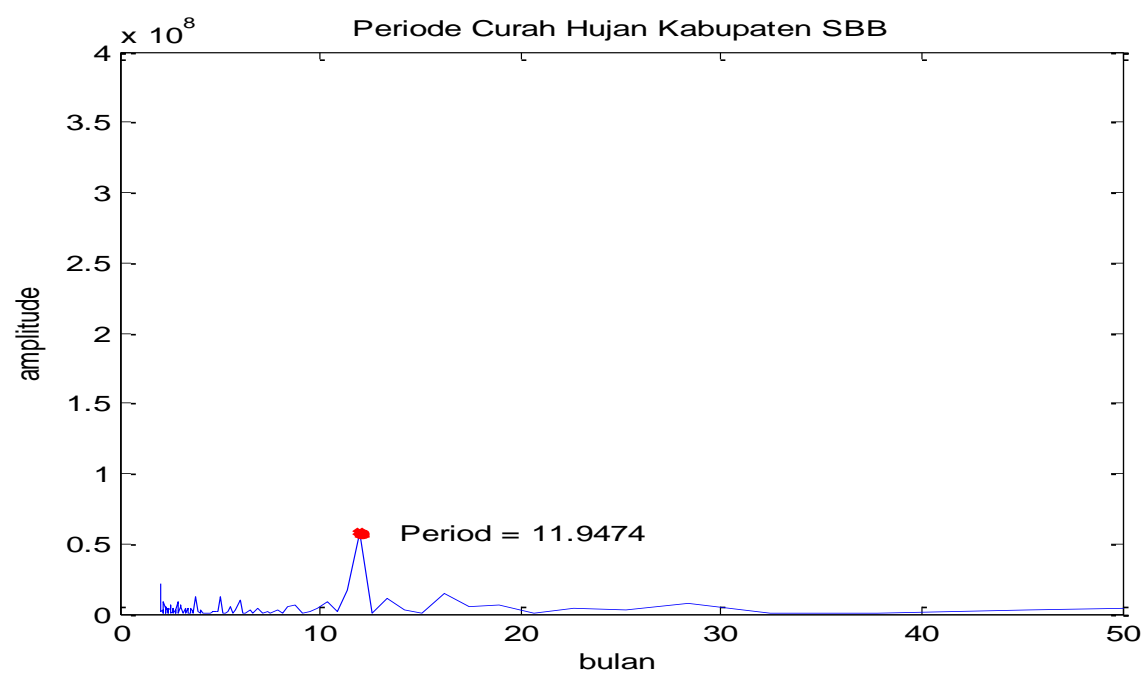

Gambar 6. Periode Maksimum Curah Hujan Kabupaten Seram Bagian Barat

\section{DAFTAR PUSTAKA}

1. Budiyanto, Setiyo., 2013., Telekomunikasi analog dan digital. Modul 1 - Sinyal dan Spektrum - Deret Fourier. Pusat Pengembangan Bahan Ajar Universitas Mercu Buana.

2. Febriani, Yeza., 2013., Jurnal Fisika. Analisis Transformasi Fourier dan Transformasi Wavelet Untuk Mengetahui Periode Curah Hujan Di Kabupaten Rokan Hulu Provinsi Riau. Universitas Pasir Pengaraian Riau, Vol. 1, No. 1.

3. Kreyszig, E.,2006., Advanced Engineering Mathematics (9th Edition)., United States: John Wiley \& Sons, Inc.

4. La Dini, Budiani., 2009., Penentuan Periode Curah Hujan Kabupaten Manokwari Menggunakan Transformasi Fourier dan Wavelet. Skripsi. Jurusan Fisika FMIPA Universitas Negeri Papua Manokwari.

5. Mathews, J.H. \& K.D. Fink., 1999., Numerical Methods Using Matlab Third Edition. Prentice Hall, Upper Saddle River, NJ 07458. 